\section{Close Approach of Mars}

Mans was in opposition with the sun on July 23, and was nearest the earth, at a distance of 36 million miles and with an angular diameter of $2 . \cdot 1^{\prime \prime}$, on July 28. Despito the closeness of the approach, the apparition is a most unfavourable one for observation in high northern latitudes. This is because of the planet's very large south declination. In Mny its declination ranged between $-22 \frac{1}{2}^{\circ}$ and $-23^{\circ}$; by the end of Juno it increased to $-2.4^{\circ}$; and it is now $-27^{\circ}$. Thus, since observations began, the altitude above the horizon in the latitude of Greenwich has never exceeded $16^{\circ}$ and is now less than $12^{\circ}$. It follows that observers in Great Britain and in most northern observatories cannot expect to get good views of the planet during the present apparition. We shall havo to rely almost entirely for our results on observers in the southern hemisphere. Astro. nomers in northern latitudes may look forward confidently to the next apparition in 1941; for then the planet will bo high in their skies and not very much farther aray from the earth. During tho present apparition, the southern hemisphere of Mars is tilted towards the earth, the latitude of the centre of the disk being $-12^{\circ}$ at the beginning of June and $-7^{\circ}$ at the end of August. Tho spring equinox of Nars' southern hemisphere occurred on June 1 ; tho summer solstice will occur on October 24 .

Is addition to the disadvantage of the planet's low altitude, English observers have had to contend with exceptionally bad weather conditions. The long spell of unsettled weather has brought with it very poor definition, which is, of course, greatly exaggerated when observations havo to bo mado near tho horizon. On the few clear nights available, Mars has generally resembled a pulsating ball of wool; and only on rare occasions, and then for brief intervals, has the disk been steady enough for the more prominent features to be made out. The south polar cap which up to the beginning of July was largo is now starting to melt rapidly. The southern maria have in general appeared fairly dark and many of the lighter regions situated in their midst have appeared shaded over. This phenomenon has been particularly striking in certain regions. Thus tho Rev. T. E. R. Phillips observed Hellas deeply shaded; and during tho last two weeks Dr. IR. L. Waterfield found the region south following the Solis Lacus to be much darker than usual. But tho Solis Lacus itself, so far as ono could seo, presented its normal configuration, and had not undergone any such striking metamorphosis as it presented in 1926 and 1928. There have been remarkablo whitenesses towards the north polar regions, which about July 10 and July 30 were almost as duzzling as the southern snow cap. These may be due to cloud, although their brilliance suggests that they are snow; but if they are due to snow, they are probably not part of the pole-cap proper, as they aro situated very eccentrically with regard to the north pole itself. It is gratifying to hear that Lr. V. M. Slipper of the Lowell Observatory has gone to Bloemfontein to observe the planet. So far, no official reports have come to hand; but according to brief reports in the Press ho has already detected some interesting changes in the Solis Lacus region, which are possibly thoso referred to above.

\section{Official Tests of 'Anderson' Shelters}

$A$ senies of official tests was recently carried out on the 'Anderson' air raid shelter, and the results published. The A.R.P. Co-ordinating Cornmittec, which is an independent body of architects, surveyors, medical men and men of science under the chairmanship of Irof. J. B. S. Mnllane, has mado some serious criticisms of these tests in a statement forwarded to Sir John Anderson. The Committeo admits that a certuin amount of useful information has been obtained, but it considers that insufficient tests were carried out to justify what it calls 'fur too optimistic' conclusions. A number of interesting points are raised; for exumple, tho Committee thinks that it is not enough to do each explosion test once only ; and if, as is claimed, apparently similar bombs often behave differently in exploding, the objection would seem to bo justified. Tho Cornmittee also asks for further research into the physiological effects of blast, a subject which is very imperfectly understood. It is well known that 'blast' is, in effect, a very rapid rise in pressure followed by a slightly slower fall. It is this rapid fluctuation of pressure, presumably, which gives blast its lethal effect. The Committeo rightly points out that there is strong evidence that it is not the magnitude of the changes in pressure which matters so much as the rato at which the pressure changes. 'The reactions of the human body to fairly slow changes of pressure have long been well known to physiologists, but thero is littlo exact knowledge of the results to be expocted when the body is subjected to wido fluctuations in a fraction of a second. If, as wo aro told, the general population is to be exposed to just such changes, the Committeo would seem to bo justified in calling for more research.

'Tre Committee's statement raises the further point that the tests indicate that in many London boroughs the population, if sheltered entirely in Anderson shelters, might be expected to suffer approximately seventeen casualties per ton of bombs dropped, and says, "When it is borno in mind that the President of the Air Raid Protection Institute estimated in March 1939, that Germany alone could despatch 3,000 tons of bombs per day to this country, the seriousness of the position will be apparent". The Committeo urges that this is further reinforcement for the case for a scheme of heavily protected shelters, particularly in fairly densely populated areas, and argues that if the tests had preceded the adoption of the official shelter policy a different policy might well havo been adopted.

\section{Saxon Time Measurement}

Is making a clearunco of earth during alterations to the Cloister Garth at Canterbury Cathedral a Saxon pocket sun-dial, or time-piece, of gold and silver was found recently at a depth of two feet. below the surface. It is described (The Times, July: 31 ) as being in the form of a tablet of silver with a gold 
cap and chain, and for gnomon a gold pin surmounted by a delicately chased animal head, with jowelled eyes and $a$ ball in its mouth. 'This pin, when not in use, rested in a holo at the lower end of the tablet, and was in this position when the time-piece was found. On the faces of the tablet aro inscribed the names of the months, abbreviated and in pairs. It the top of each of the three columns is a hole for the pin when in uso, and below each holo two spots. Of theso the higher in each month, when the dial hangs frec, indicates noon and tho lower 9 a.m. and 3 p.m. marking the hours of the monks' services. Along the edges runs the inscription: Pax PossessoriSalus Factori. Tho dial has been tested for accuracy by Dr. A. H. Smith of University Collego, London. The grouping of the months in pairs according to their equivalent distances from the summer solstice is based, it is to bo presumed, on the table given by I3edo for measuring the shadow of a six-foot gnomon. Dr. Smith finds that owing to its small size, tho dial could only bo approximately accurate. It would, however, bo moro or less correct at noon in latitudo 5) $3^{\circ} \mathrm{N}$. at the middle of certain months, or early in others, while in the far north of England it would bo more or less accurate through tho summer months. At 9 a.m. and 3 p.m. it would bo moro or less accurato in late January, mid-February, mid-. Iarch, early April, carly May, lato July, mid-September, early October, early November and early December.

\section{Anglo-Saxon Ship Burial}

Ship bURials are of sufficient rarity, oven on the Continent, for the discovery of an Anglo-Saxon ship burial at Sutton Ifoo, near Ipswich (The Times, July 26, July 31) to be regarded as a memorable and, indeed, remarkable event. This is, in fuct, only the second of the kind to be found in Erigland, a previous discovery, though of a rather less impressive character, having been mado at Snape, two miles away. In the present instance, the vessel in which the interment had taken place was a rowing galley $82 \mathrm{ft}$. long. The quantity and character of the jewellery and other personal objects associated with the burial wero such as to justify tho assumption that a chief lay buried here. The personal relics were found collected together in tho centre of tho ship, and included a handsome gold buckle, clasps and fastenings of the garments, gold studs from a belt, and small plaques of gold bearing figures of human beings and unimals. The sword had been laid by the side of the body; but it has almost entirely perished, with the exception of the richly ornamented gold and jewelled pommel. The deceased had also been provided with money, tho remains of a purse being found beside some coins. Other articles found with the burial were iron pots and spearheads, and an object which has the appearance of a sceptre, having faces carved at either end. A metal cup may, it is thought, have contained some articles of symbolic significance. The grave is situated on the estate of Mrs. E. M. Pretty, and has been excavated by tho authorities of the Ipswich Museum, under the field direction of Mr. Guy Maynard, with the co-operation of H.M. Office of Works and the British Mluseum.

\section{Lightning Flashes and High Tension Mains}

Dunis: July there were many violent thunderstorms and much damage was dono to overhead electric mains and substations connected with them. The damage done to main stations was also sovere. On July 19, a violent thunderstorm cut off Valley Road Power Station at. Bradford from tho Grid and shut down all tho generating sets thero. For about an hour, mills, factories, trams and trolley-buses on many routes camo to a standstill; the traffic lights failed and there was no light anywhere for about an hour. A similar occurrence took place at the Brighton Power Houso at Southwick. In both cases the difficulties of the staff were increased as they wero engaged in changing over on the Grid supply from $6 \cdot 6$ kilovolt to 33 kilovolt. There was a heavy storm over Cumberland and the overhead transmission was struck. This affected the supply to more than 30,000 houses in Cockermouth, Maryport, Aspatria and Wigton as well as part of Workington, the lights being out from 3.15 p.m. to 8.30 p.m. On July 19 , at 8 p.m., the B.I3.C. National Transmitter at Droitwich was struck by lightning and put out of action. The flashes striking the 700-ft. masts of the Radio Station wero extremely violent. Flames shot from the cage of aerial wires slung between tho masts. In somo places transformers or switchgear wero damaged and three fires broko out, destroying substation roofs or walls. Since thunderstorms aro less frequent in Great Britain than in South Africa and other parts of the world it might be useful to study the effects of modern lightning protectors in protecting poles, steel towers, overhead mains, etc.. in places whero thunderstorms aro frequent and violent. Also when designing new grids or extensions of old ones to get estimates of the relativo costs of overhead mains and of underground mains. A decision could then bo arrived at as to which is tho better method of transmitting high-tension electric power.

\section{Empire Broadcasts on Scientific Topics}

TuE I3ritish I3roadcasting Corporation has instituted a short series of quarter-hour broadcasts to the Empire on recent advances in science. The first talk of the series was given at 11.15 p.m. on July 31 by Yrof. Allan Ferguson, one of the general secretaries of the British Association. Prof. Ferguson, after giving $a$ simple picture of the structure of the atom, and the results to be expected from atomic bombardment, described briefly tho dovelopment of the cyclotron, recent experiments on nuclear disintegration, including the uranium-fission experiments, and the production of 'labelled' particles. Succeding talks will bo given by Wing-Commander Cave-Browne-Cnvo on mechanical engineering (August 7), by Dr. S. J. F. Philpott on psychology (August 14) and by Prof. F.A. E. Crew on biology (August 21).

\section{League of Nations}

"The League from Year to Year (1938)", which has recently been issued by the Information Section of the Secretariat of the League of Nations, contains the usual concise account of the year's activities in 